\title{
How did the US EPA and IARC reach diametrically opposed conclusions on the genotoxicity of glyphosate-based herbicides?
}

\author{
Charles M. Benbrook ${ }^{*}$
}

\begin{abstract}
Background: The US EPA considers glyphosate as "not likely to be carcinogenic to humans."The International Agency for Research on Cancer (IARC) has classified glyphosate as "probably carcinogenic to humans (Group 2A)." EPA asserts that there is no convincing evidence that "glyphosate induces mutations in vivo via the oral route." IARC concludes there is "strong evidence" that exposure to glyphosate is genotoxic through at least two mechanisms known to be associated with human carcinogens (DNA damage, oxidative stress). Why and how did EPA and IARC reach such different conclusions?

Results: A total of 52 genotoxicity assays done by registrants were cited by the EPA in its 2016 evaluation of technical glyphosate, and another 52 assays appeared in the public literature. Of these, one regulatory assay (2\%) and 35 published assays (67\%) reported positive evidence of a genotoxic response. In the case of formulated, glyphosatebased herbicides (GBHs), 43 regulatory assays were cited by EPA, plus 65 assays published in peer-reviewed journals. Of these, none of the regulatory, and 49 published assays (75\%) reported evidence of a genotoxic response following exposure to a GBH. IARC considered a total of 118 genotoxicity assays in six core tables on glyphosate technical, GBHs, and aminomethylphosphonic acid (AMPA), glyphosate's primary metabolite. EPA's analysis encompassed 51 of these 118 assays (43\%). In addition, IARC analyzed another 81 assays exploring other possible genotoxic mechanisms (mostly related to sex hormones and oxidative stress), of which 62 (77\%) reported positive results. IARC placed considerable weight on three positive GBH studies in exposed human populations, whereas EPA placed little or no weight on them.
\end{abstract}

Conclusions: EPA and IARC reached diametrically opposed conclusions on glyphosate genotoxicity for three primary reasons: (1) in the core tables compiled by EPA and IARC, the EPA relied mostly on registrant-commissioned, unpublished regulatory studies, 99\% of which were negative, while IARC relied mostly on peer-reviewed studies of which $70 \%$ were positive (83 of 118); (2) EPA's evaluation was largely based on data from studies on technical glyphosate, whereas IARC's review placed heavy weight on the results of formulated GBH and AMPA assays; (3) EPA's evaluation was focused on typical, general population dietary exposures assuming legal, food-crop uses, and did not take into account, nor address generally higher occupational exposures and risks. IARC's assessment encompassed data from typical dietary, occupational, and elevated exposure scenarios. More research is needed on real-world exposures to the chemicals within formulated GBHs and the biological fate and consequences of such exposures.

Keywords: Glyphosate, Roundup, Genotoxicity, Cancer, IARC, US EPA, Co-formulants, Occupational exposure, Regulation

*Correspondence: charlesbenbrook@gmail.com

Benbrook Consulting Services, Enterprise, OR, USA 


\section{Background}

Markedly different judgements have been reached by the US Environmental Protection Agency (EPA), European regulators, and the International Agency for Research on Cancer (IARC) regarding the potential of glyphosatebased herbicides (GBHs) to cause or contribute to human cancer. The EPA and European regulators have concluded that glyphosate technical poses no significant cancer risks to the general public, based on currently approved, foodcrop uses and the levels of dietary exposure expected in the general population (including residues in drinking water and beverages) [1-3].

In the IARC summary of the rationale for its Group 2A "probably carcinogenic to humans" classification of glyphosate and GBHs, the Working Group wrote "there is strong evidence that glyphosate can operate through two key characteristics of known human carcinogens, and that these can be operative in humans": genotoxicity (DNA damage) and oxidative stress [4].

In reference to the "strong evidence" of genotoxicity in its summary statement, the IARC Working Group highlighted a study in an exposed, human population (presumably Bolognesi et al. [5]) in which "markers of chromosomal damage (micronucleus formation) were significantly greater after exposure than before exposure in the same individuals" [4].

Also according to the IARC Working Group, there is "strong evidence" that glyphosate, GBHs, and glyphosate's major metabolite AMPA can induce oxidative stress in animal studies and in in vitro human cell assays. Moreover, IARC stressed that observed oxidative stress in several assays was ameliorated by administration of an antioxidant, lending further support to this second mechanism of action (e.g. [6, 7]).

In March 2015, IARC classified glyphosate and GBHs as "probably carcinogenic to humans" [8]. This unexpected classification set off intense debate across and among key scientific and regulatory institutions, the original registrant of GBHs (Monsanto), and scientists publishing research on, or relevant to the assessment of GBH carcinogenicity [9-14].

IARC initially released its full Monograph Volume 112 report on glyphosate and GBH carcinogenicity on July 29,2015 , and subsequently issued a slightly revised, final version in January 2017 [4]. A summary of the IARC's classification decision was first published online March 25, 2015 in Lancet Oncology [8]. As the case with all IARC reviews, the Working Group assessing glyphosate and GBH carcinogenicity relied predominantly on publicly available, peer-reviewed studies. The basis of IARC's Group 2A "probably carcinogenic to humans" classification is summarized in Sect. 6.4 "Rationale" in the Monograph Volume 112 report, and reads in part:
"In making this overall evaluation, the Working Group noted that the mechanistic and other relevant data support the classification of glyphosate in Group 2A. In addition to limited evidence for the carcinogenicity of glyphosate in humans and sufficient evidence for the carcinogenicity of glyphosate in experimental animals, there is strong evidence that glyphosate can operate through two key characteristics of known human carcinogens, and that these can be operative in humans" [4].

\section{Focus of EPA and EFSA glyphosate risk assessments}

Recent regulatory judgements on glyphosate cancer risk in the US and Europe are based upon an assessment of general population, dietary exposures under typical conditions, and do not take into account, nor reflect a detailed evaluation of the sometimes much-higher levels of exposure that occur in a variety of occupational mixer/ loader and applicator scenarios [15], e.g., hand-held, backpack, ATV, and truck-mounted sprayers that require a person to hold and direct an application wand. Such applications lead to much higher dermal exposures compared to applicators working inside tractor or sprayer cabs. In addition, applying a GBH many days per year for several hours per day inevitably leads to greater, routine dermal exposures, as well as more numerous incidents during which significantly greater than normal exposures occur because of a leaky hose or value, wind conditions, a spill, or other unusual or unforeseen circumstance.

EPA's comprehensive report on the carcinogenicity of glyphosate was released in September 2016 [3]. After presenting a detailed assessment of registrant-conducted animal bioassays, published epidemiological studies, and the genotoxicity database on glyphosate technical (but not GBHs, see below for why), Sect. 6.6 of the EPA report contrasts the information and evidence the agency reviewed relative to the five different cancer classifications set forth in its 2005 cancer guidelines: carcinogenic to humans; likely to be carcinogenic to humans; suggestive evidence of carcinogenic potential; inadequate information to assess carcinogenic potential; and, not likely to be carcinogenic to humans [16]. These classifications are roughly equivalent to IARC's categories: Group 1 (carcinogenic to humans); Group 2A (probably carcinogenic); Group 2B (possibly carcinogenic); Group 3 (not classifiable); and, Group 4 (probably not carcinogenic) [17].

Based on EPA's weight-of-the-evidence review of data mostly from studies on glyphosate technical, the agency concluded that "The strongest support is for 'not likely to be carcinogenic to humans' at doses relevant for human health risk assessment" (emphasis added) [3]. Such "relevant doses," as discussed in the EPA assessment, arise 
from residues in food and beverages following legal, labelled food-crop applications of a GBH.

Other regulatory authorities have mostly concurred with the EPA's judgement, for essentially the same reasons $[1,2,18]$. Regulatory agencies other than the US EPA cite mostly the same set of registrant-conducted studies as EPA, supplemented to one degree or another, by a portion of the studies in the peer-reviewed literature that formed the primary basis of IARC's review.

Since March of 2015, papers have been published generally supporting and/or defending the IARC determination [9, 10, 19-21], while others have criticized IARC's conclusion and/or addressed why the EPA and other regulatory-agency judgements should be accepted as more surely based on "sound science" [2, 14, 22, 23]. A few papers have attempted to explain why IARC and the US EPA reached such different conclusions [11, 24]. IARC distributed a January 2018 "Briefing Note for IARC Scientific and Governing Council Members" responding to a number of criticisms and erroneous claims regarding the deliberations of the Working Group [25].

\section{GBHs should be the focus of risk assessments}

It is important to emphasize that in the case of glyphosate, the vast majority of registrant-conducted animal studies, and all the chronic studies, have dosed animals with technical glyphosate. Hence, the key toxicological parameters embedded in EPA and other regulatory, human-health risk assessments reflect risks stemming from exposure to glyphosate technical in the absence of co-formulants.

This is inappropriate for three reasons: (1) formulated GBHs account for all commercial uses and human exposures (no herbicide products contain just glyphosate), (2) regulators are aware that the co-formulants in GBHs markedly alter the absorption, distribution, metabolism, excretion, and possibly the toxicity, of the glyphosate in formulated GBHs [1-3]; and (3) multiple studies report that formulated GBHs are more toxic than glyphosate technical (see Table 3 for references and accompanying discussion).

The three major pillars of the EPA and IARC evaluations of GBH oncogenic risk to humans are animal bioassays, epidemiological studies in exposed populations, and genotoxicity studies useful in determining whether there are plausible mechanism(s) through which exposure to GBHs might trigger or accelerate cancerous cell growth. Differences exist in the EPA's and IARC's assessments of animal bioassay and epidemiological data, but by far the most pronounced, and consequential differences arise in the area of GBH genotoxicity.

Taking full account of differences in the absorption, distribution, metabolism, excretion, and toxicity of technical or "pure" glyphosate, in contrast to formulated, glyphosate-based herbicides (GBHs) poses many challenges for regulators, scientists, and glyphosate manufacturers. According to the European Food Standards Agency (EFSA), the purity of glyphosate technical in its evaluation and risk assessment ranges between $95 \%$ and $98.3 \%$ glyphosate [2]. Impurities including $N$-nitroso-glyphosate and formaldehyde make up no more than $1.1 \%$ of technical glyphosate [2]. Formulated GBHs, on the other hand, typically contain between 2 and $60 \%$ glyphosate and a fraction of $1 \%$ to $25 \%$ adjuvants, surfactants, and other co-formulants.

This analysis strives to shed light on why EPA and IARC reached diametrically opposed judgements regarding GBH genotoxicity. The science base cited and relied upon by the EPA and IARC in their full evaluation reports are contrasted, and also compared to the set of studies addressed in several Monsanto-commissioned review articles [14, 22, 26, 27]. Differences in the evidentiary foundation and technical focus of the EPA and IARC, as they undertook their genotoxicity assessments, are described, as are the ways these differences altered the weight accorded to different studies and lines of evidence.

\section{Methods}

Section 5.3 of the September 2016 EPA evaluation of glyphosate carcinogenicity [3] includes seven tables setting forth the assays the agency considered in the following areas:

- Table 5.1. In vitro test for gene mutation in bacteria: glyphosate technical (hereafter Bacterial Reverse Mutation Studies);

- Table 5.2. In vitro mammalian gene mutation assays: glyphosate technical;

- Table 5.3. In vitro tests for chromosomal aberrations in mammalian cells-glyphosate technical;

- Table 5.4. In vitro tests for micronuclei induction in mammalia cells-glyphosate technical;

- Table 5.5. In vivo tests for chromosomal aberrations in mammals-glyphosate technical;

- Table 5.6. In vivo tests for micronuclei induction in mammals-glyphosate technical; and

- Table 5.7. Assays for detecting primary DNA damage-glyphosate technical (hereafter DNA Damage).

Each of these seven tables reports the Test/Endpoint; Test [assay] System; Route of Administration; Doses/ Concentration; Test Material Purity (when known); Results; References; and, Comments. "Results" typically are "positive" or "negative," and sometimes specify the conditions under which a positive/negative response 
was reported (e.g., "Negative \pm S9"; "Positive, Statistically significant $[p<0.05]$ increase in $\mathrm{MN}$ at 15 and $20 \mathrm{mg} / \mathrm{L}$ ).

The assay-by-assay information in these core tables was moved into an Excel workbook, in which the following data were recorded: Year, Author, Result, whether the assay was conducted by a registrant (Regulatory) or was published in the Public Literature, and Comments. All of the above information is recorded as reported in the EPA tables noted above. The assay results described in the EPA tables were chosen by the agency, and usually were also noted in each study's abstract.

Each of this paper's tables is organized according to whether an assay was conducted with glyphosate technical (Glyphosate), or a formulated GBH. Also included is whether a study or assay was cited by EPA 2016, IARC 2017, and/or a Monsanto-commissioned review. Additional file 1: Tables S1-S7 include the above information for the studies and assays cited by EPA in seven core tables (Tables 5.1-5.7).

In addition, the EPA listed studies on glyphosate-based formulations separately in Appendix F, "Genotoxicity Studies with Glyphosate Based Formulations" [3]. Assays in Tables F.1, F.2, F.3, F.4 and F.5 were added to Additional file 1: Tables S1-S7, and incorporated in the present analysis.

Summary statistics by type of genotoxicity test and assay system were calculated for studies on glyphosate technical and formulated GBHs. For regulatory studies, public literature studies, and all studies, the number of studies, number of positives, and percent positive were calculated.

A similar Excel worksheet was constructed from all glyphosate-related genotoxicity studies and assays cited in Volume 112 of the IARC Monograph series in "Sect. 4.2 Mechanisms of carcinogenesis" [4]. The IARC Working Group organized its assessment of genotoxicity data in six core tables:

- Table 4.1 Genetic and related effects of glyphosate in exposed humans;

- Table 4.2 Genetic and related effects of glyphosate, AMPA, and glyphosate-based formulations in human cells in vitro;

- Table 4.3 Genetic and related effects of glyphosate, AMPA, and glyphosate-based formulations in nonhuman mammals in vivo;

- Table 4.4 Genetic and related effects of glyphosate, AMPA, and glyphosate-based formulations in nonhuman mammalian cells in vitro;

- Table 4.5 Genetic and related effects of glyphosate, AMPA, and glyphosate-based formulations in nonmammalian systems in vivo; and
- Table 4.6 Genetic and related effects of glyphosate and glyphosate-based formulations on non-mammalian systems in vitro.

Each of the above six, IARC tables covers studies and assays done on glyphosate technical, as well as any studies/assays conducted using a formulated GBH. A few studies testing the primary glyphosate metabolite aminomethylphosphonic acid (AMPA) are also included in the IARC tables. As in the case of the core EPA tables, the IARC Working Group selected the assays to describe from each study. With a few exceptions entailing indeterminate results, each assay was designated as "positive" or "negative" for genotoxicity. Hence, the information in this paper's tables on assays considered by the IARC Working Group reflect that Working Group's judgements regarding which of the assays were scientifically valid, relevant, and which indicated genotoxic potential versus those that did not.

For these six IARC tables, the following information was recorded in the Excel workbook: Category of Study, Citation (lead author(s) and year), End-point Studied, Test/Assay, Response/Results, and Comments. In addition, the tables note whether a given study/assay was cited in a Monsanto-commissioned Review (yes/no) [14, 22, 26, 27] and/or in the EPA's September 2016 report [3]. Summary statistics are calculated by IARC assay category. Additional file 1: Table S8 lists the genotoxicity studies and assays considered by the IARC Working Group and records the information described above.

Assays cited by IARC and recorded in Additional file 1: Table S8 were then added to Additional file 1: Tables S1S7, allowing comparison of the number of studies and assays in each of the categories that were cited by EPA, IARC, or both.

In addition to the assays cited by IARC in Tables 4.14.6, additional studies are discussed in the narrative of the IARC Monograph 112 in Sects. 4.2.2-4.2.4. These studies are related to mechanisms of genotoxicity other than those listed in the core tables. The majority of these studies explore sex hormone disruption and oxidative stress. For studies cited in the narrative sections of IARC 2017, the following information was recorded in Additional file 1: Table S9: Citation (lead author(s) and date), Category, Study type, End-point studied, and Result.

The data in Additional file 1: Tables S1-S9 are integrated and summarized in Additional file 1: Table S10. This table lists all assays considered by the EPA and IARC, and breaks them down by source (Regulatory or Public Literature) and result (Total Number, Number Positive, and Percent Positive). Finally, Additional file 1: Table S11 reports, for the core IARC and EPA tables, the number and results of assays considered by IARC but not 
by EPA, and the number considered by EPA but not by IARC.

Note that many of the studies cited by IARC and EPA report results in more than one test system or assay. Other studies cover assays testing glyphosate technical, AMPA, and formulated GBHs. As a result, the total number of reported assay results for glyphosate technical, AMPA, and GBHs exceeds the number of studies cited by EPA, IARC, or in any, or all of the four Monsantocommissioned reviews [14, 22, 26, 27]. Also, EPA and IARC utilize somewhat different classification systems and methods for recording assay results, altering the number of assay results reported from a few studies $(\sim 9$ assays), and account for minor differences in the assay counts across Additional file 1: Tables S1-S11.

Throughout this paper, a "negative" assay is one reported as negative across all dose levels, as well as across all alternative ways a given assay was conducted; a "positive" assay is one where the authors reported, and IARC and/or EPA concurred, that there was at least one statistically significant genotoxic response at one or more dose levels.

\section{Results}

Table 1 provides an overview of the database available as of early 2015 for evaluation of the genotoxicity of glyphosate and glyphosate-based herbicides (GBHs). The seven categories of studies in Table 1 cover assays cited by EPA and/or IARC in their analyses [3, 4]. Across all categories, a total of 52 regulatory assays were cited by EPA on glyphosate technical. Another 52 assays appeared in the public literature and were cited by EPA, IARC, or both, for a total of 104 assays on glyphosate technical.

Of the total 104 assays on glyphosate technical, one regulatory assay and 35 published assays reported positive evidence of a genotoxic response, for a total of 36 positive assays in the case of glyphosate technical. Thus, for glyphosate technical just $2 \%$ of the regulatory assays and $67 \%$ of the assays published in peer-reviewed journals reported positive results.

While EPA did not consider any assays on AMPA, IARC's analysis did include five assays on the genotoxicity of this major metabolite of glyphosate (all positive).

In the case of formulated GBHs, 43 regulatory assays and 65 assays from published literature were cited by EPA and/or IARC, for a total of 108 . Of these 108, none of the regulatory assays reported evidence of a positive genotoxic response, while 49 published assays did (75\%).

Bacterial reverse mutation assays accounted for 51 out of the 95 (54\%) regulatory assays submitted to EPA on glyphosate technical and formulated GBHs. There were a total of 29 assays on glyphosate technical exploring direct DNA damage cited by EPA, mostly COMET and sister chromatid exchange assays. Of these 29 assays, 27 were reported in public literature studies.

Table 2 reports the number of assays on glyphosate technical, AMPA, and formulated GBHs cited by IARC in the following six categories of studies:

- Exposed humans category (GBHs);

- Human cells in vitro categories (glyphosate technical, AMPA, GBHs);

- Non-human mammals in vivo categories (glyphosate technical, AMPA, GBHs);

- Non-human mammalian cells in vitro categories (glyphosate technical, AMPA, GBHs);

- Non-mammalian systems in vivo categories (glyphosate technical, AMPA, GBHs); and

- Non-mammalian systems in vitro categories (glyphosate technical, GBHs).

In addition, for each category of study, Table 2 reports the number of assays that were also cited in one or more of the four Monsanto-commissioned reviews [14, 22, 26, 27] and by EPA in its September 2016 report [3].

Across all categories of studies in its six core tables, IARC considered 118 assays. Of these, Monsanto-commissioned reviews cited $84(71 \%)$ and the EPA cited $51(43 \%)$. In general, both scientists and regulators [3] place greater emphasis on mammalian assay systems, in contrast to non-mammalian systems, in evaluating the mechanisms of toxicity in humans following exposure to pesticides. As shown in Table 2, the IARC Working Group cited 54 mammalian assays, and 49 (91\%) and 40 (74\%) of these were cited in the Monsanto-commissioned reviews and by the EPA, respectively.

Of the 51 assays cited by both the EPA and IARC, 24 report the impact of exposures to GBHs, but these were given little weight in the EPA's assessment of the genotoxicity of glyphosate (see "Discussion"). Therefore, EPA's conclusion regarding the genotoxicity of glyphosate was based predominantly on the agency's review of 27 assays out of the 118 assays assessed by IARC (51 total IARC and EPA assessed assays, minus 24 on GBHs not focused on by EPA).

Hence, in its evaluation of glyphosate genotoxicity, the EPA took fully into account the results of only $23 \%$ of the assays considered by IARC (27/118). In addition, Additional file 1: Table S11 shows that the EPA took into account 61 registrant-commissioned assays on glyphosate technical and 48 registrant assays on GBHs that were not considered by the IARC Working Group. Of these 109 assays, seven (6.4\%) were positive. In terms of focus, 54 of the 109 assays (49.5\%) were from bacterial reverse mutation studies (all negative), and 31 (28.4\%) were in vivo micronuclei induction assays (30 negative). 
Table 1 Genotoxicity assays on glyphosate and formulated GBHs by registrants ("Reg.") and in public literature ("Pub.")

\begin{tabular}{|c|c|c|c|c|c|c|c|c|c|}
\hline \multirow{2}{*}{$\begin{array}{l}\text { Assay type and compound } \\
\text { tested }\end{array}$} & \multicolumn{3}{|c|}{ Number of assays } & \multicolumn{3}{|c|}{ Number of positives } & \multicolumn{3}{|c|}{ Percent positive } \\
\hline & Reg. & Pub. & Total & Reg. & Pub. & Total & Reg. (\%) & Pub. (\%) & Total (\%) \\
\hline \multicolumn{10}{|l|}{ Bacterial reverse mutation } \\
\hline Glyphosate technical & 23 & 4 & 27 & 0 & 0 & 0 & 0 & 0 & 0 \\
\hline Formulated GBHs & 28 & 3 & 31 & 0 & 1 & 1 & 0 & 33 & 3 \\
\hline \multicolumn{10}{|c|}{ In vitro and in vivo mammalian gene mutation } \\
\hline Glyphosate technical & 4 & 2 & 6 & 0 & 1 & 1 & 0 & 50 & 17 \\
\hline Formulated GBHs & 0 & 1 & 1 & 0 & 1 & 1 & 0 & 100 & 100 \\
\hline \multicolumn{10}{|c|}{ In vitro chromosomal aberration } \\
\hline Glyphosate technical & 4 & 5 & 9 & 0 & 3 & 3 & 0 & 60 & 33 \\
\hline AMPA & 0 & 1 & 1 & 0 & 1 & 1 & 0 & 100 & 100 \\
\hline Formulated GBHs & 0 & 2 & 2 & 0 & 1 & 1 & 0 & 50 & 50 \\
\hline \multicolumn{10}{|c|}{ In vitro micronuclei induction in mammals } \\
\hline Glyphosate technical & 0 & 6 & 6 & 0 & 4 & 4 & 0 & 67 & 67 \\
\hline \multicolumn{10}{|l|}{ In vivo chromosomal aberration } \\
\hline Glyphosate technical & 5 & 2 & 7 & 0 & 2 & 2 & 0 & 100 & 29 \\
\hline Formulated GBHs & 0 & 8 & 8 & 0 & 6 & 6 & 0 & 75 & 75 \\
\hline \multicolumn{10}{|c|}{ In vivo micronuclei induction in mammals } \\
\hline Glyphosate technical & 14 & 6 & 20 & 1 & 2 & 3 & 7 & 33 & 15 \\
\hline AMPA & 0 & 1 & 1 & 0 & 1 & 1 & 0 & 100 & 100 \\
\hline Formulated GBHs & 15 & 13 & 28 & 0 & 7 & 7 & 0 & 54 & 25 \\
\hline \multicolumn{10}{|l|}{ DNA damage } \\
\hline Glyphosate technical & 2 & 27 & 29 & 0 & 23 & 23 & 0 & 85 & 79 \\
\hline AMPA & 0 & 3 & 3 & 0 & 3 & 3 & 0 & 100 & 100 \\
\hline Formulated GBHs & 0 & 38 & 38 & 0 & 33 & 33 & 0 & 87 & 87 \\
\hline \multicolumn{10}{|l|}{ All assays } \\
\hline Glyphosate technical & 52 & 52 & 104 & 1 & 35 & 36 & 2 & 67 & 35 \\
\hline AMPA & 0 & 5 & 5 & 0 & 5 & 5 & 0 & 100 & 100 \\
\hline Formulated GBHs & 43 & 65 & 108 & 0 & 49 & 49 & 0 & 75 & 45 \\
\hline All tested compounds & 95 & 122 & 217 & 1 & 89 & 90 & 1 & 73 & 41 \\
\hline
\end{tabular}

1. Table includes assays on glyphosate technical cited in EPA's 2016 "Glyphosate Issue Paper: Evaluation of Carcinogenic Potential", Sect. 5: Data Evaluation of Genetic Toxicity, Table 5.1, 5.2, 5.3, 5.4, 5.5, 5.6, and 5.7. Assays on formulated GBHs considered by EPA come from Tables F.1, F.2, F.3, F.4 and F.5 in Appendix F: "Genotoxicity Studies with Glyphosate Based Formulations" [3]

2. Also included are additional assays on glyphosate technical, AMPA, and formulated GBHs from IARC Monograph 112 on the carcinogenicity of glyphosate [4] from Tables 4.1, 4.2, 4.3, 4.4, 4.5, or 4.6

3. Additional file 1: Tables S1-S7 list all assays in the core tables from EPA 2016 [3] and IARC 2017 [4] based on genotoxicity assay type

Additional file 1: Table S11 also shows that IARC analyzed 21, 41, and 5 published assays (total 67), respectively, on glyphosate technical, GBHs, and AMPA that were not reviewed or given weight by the EPA, 55 (82\%) of which were positive.

In order to accurately describe the full genotoxicity database evaluated by IARC, several additional studies and assays cited in the Volume 112 narrative report have been added to Additional file 1: Table S9 and are summarized in Additional file 1: Table S10. There were 82 assays involving other potential mechanisms of genotoxicity (mainly sex hormone disruption and oxidative stress) that were evaluated by the IARC Working Group and referenced in the narrative section of IARC 2017. These include an additional 53 assays on glyphosate technical, 4 on AMPA, and 25 on formulated GBHs, $77 \%$ of which reported positive results.

When included in the overall analysis (see Additional file 1: Table S10), these additional assays bring the total number considered by IARC or EPA to $306,51 \%$ of which report positive results. 211 of these 306 assays are from the public literature, $74 \%$ of which reported one or more positive result. 
Table 2 Number of genotoxicity assays cited in core tables by IARC 2017, EPA 2016, or in Monsanto-commissioned reviews

\begin{tabular}{|c|c|c|c|}
\hline \multirow[t]{2}{*}{ Assay type and compound tested } & \multirow{2}{*}{$\begin{array}{l}\text { Number of studies considered } \\
\text { by IARC }\end{array}$} & \multicolumn{2}{|l|}{ Cited by } \\
\hline & & MON reviews & EPA Sept 2016 \\
\hline \multicolumn{4}{|l|}{ Exposed humans } \\
\hline Formulated GBHs & 5 & 5 & 0 \\
\hline \multicolumn{4}{|l|}{ Human cells in vitro } \\
\hline Glyphosate & 10 & 8 & 7 \\
\hline AMPA & 2 & 2 & 0 \\
\hline Formulated GBHs & 4 & 2 & 3 \\
\hline \multicolumn{4}{|l|}{ Non-human mammals in vivo } \\
\hline Glyphosate & 11 & 10 & 10 \\
\hline AMPA & 1 & 1 & 0 \\
\hline Formulated GBHs & 13 & 13 & 13 \\
\hline \multicolumn{4}{|l|}{ Non-human mammalian cells in vitro } \\
\hline Glyphosate & 5 & 5 & 5 \\
\hline AMPA & 1 & 1 & 0 \\
\hline Formulated GBHs & 2 & 2 & 2 \\
\hline \multicolumn{4}{|l|}{ Non-mammalian systems in vivo } \\
\hline Glyphosate & 12 & 7 & 1 \\
\hline AMPA & 2 & 2 & 0 \\
\hline Formulated GBHs & 40 & 21 & 4 \\
\hline \multicolumn{4}{|l|}{ Non-mammalian systems in vitro } \\
\hline Glyphosate & 8 & 3 & 4 \\
\hline Formulated GBHs & 2 & 2 & 2 \\
\hline Total all categories & 118 & 84 & 51 \\
\hline As percent of total IARC & & $71 \%$ & $43 \%$ \\
\hline Total of all mammalian categories & 54 & 49 & 40 \\
\hline As percent of total IARC & & $91 \%$ & $74 \%$ \\
\hline
\end{tabular}

1. IARC totals are from the detailed accounting of all studies considered by the IARC Working Group in the glyphosate section of Monograph 112 [4]. Information on the studies are taken from Tables 4.1-4.6 and the discussion of studies on oxidative stress in humans in Sect. 4.2.3 (a) (i) of the monograph

2. "MON Reviews" include four published studies: Brusick et al. [22]; Kier and Kirkland [27]; Heydens et al. [26]; and Williams et al. [14]. The references in these four, Monsanto-commissioned reviews were cross-checked against the list of IARC studies

3. "EPA Sept 2016" refers to the September 12, 2016 "Glyphosate Issue Paper: Evaluation of Carcinogenic Potential" [3]. All studies cited in this EPA document, including in its Appendix F which contains studies on formulated glyphosate-based herbicides, were cross-checked against the studies cited by IARC and in the Monsantocommissioned reviews

The tendency of scientists to not disseminate or seek publication of "negative" studies is likely not a factor in the case of registrant-commissioned lab studies of glyphosate and GBHs, the majority of which are submitted to regulators and report mostly negative results. A substantial share ( $27 \%)$ of published assays on glyphosate or GBHs done by scientists not working for pesticide manufacturers reported negative results. There is no way of knowing how many additional assays have been done by registrants with negative or positive results that were never submitted to regulators, nor published. It is also not possible to project the number of assays done by scientists not working for industry that showed positive or negative signs of genotoxicity, but were not published.

\section{Discussion}

In the IARC Working Group's "Exposed Humans" table, three studies are cited assessing chromosomal aberrations, DNA strand breaks, and micronuclei formation in five populations of exposed people [5, 28, 29]. Positive evidence of genotoxicity was reported in four of the five populations. Only Bolognesi et al. [5] was cited in the EPA's Appendix F Table F.5. "Other assays for detecting DNA damage-glyphosate formulations" [3]. The introduction to Appendix F states the following:

"While the focus of this analysis is to determine the genotoxic potential of glyphosate, the agency has identified numerous studies conducted with glyphosate-based formulations that contain various con- 
centrations of the glyphosate as well as other components of the end use products and are presented in Tables F.1-F.5" [3].

In the introduction to Sect. 5 on genotoxicity in its 2016 report, the EPA writes:

"Studies conducted with glyphosate formulations that were identified and considered relevant for genotoxicity evaluation are summarized in table form in Appendix F. As described in Sect. 7.0 of this document, glyphosate formulations are hypothesized to be more toxic than glyphosate alone. The agency is collaborating with NTP [National Toxicology Program] to systematically investigate the mechanism(s) of toxicity for glyphosate and glyphosate formulations. However, the focus of this section [Sect. 5 on genotoxicity] is the genotoxic potential of glyphosate technical" [3].

In the above passages, the EPA makes clear that it based its judgment regarding the genotoxicity of glyphosate and GBHs predominantly on studies conducted with glyphosate technical. EPA's choice of words in discussing differences in the toxicity of formulated GBHs in contrast to glyphosate technical is hard to square with the results of multiple, published studies.

\section{Differential toxicity}

EPA regards such differences as "hypothesized," despite many studies reporting that GBHs are, in general, more toxic than glyphosate technical [30-32], and sometimes by large margins [33, 34], as shown in Table 3 . The examples of differential toxicity in Table 3 are based on the levels of glyphosate technical triggering a defined, positive genotoxicity response in a given assay, in contrast to the amount of glyphosate in a GBH that triggers the same response. Accordingly, such comparisons are limited to a specific assay and marker of biological response and should be interpreted as only one of many indicators of the relative toxicity of a dose of glyphosate in a GBH compared to the same dose of glyphosate in the absence of co-formulants.
The reasons why the glyphosate in GBHs is more toxic than the same amount of glyphosate technical are generally agreed upon. Most of the surfactants used in the formulation of GBHs are designed to accelerate the movement of glyphosate across plant surface membranes and also foster the movement of glyphosate into mammalian cells [31, 35]. Many co-formulants are more toxic than technical glyphosate [31,36] and synergistic activity may occur in some exposure scenarios with certain formulations. Accordingly, differential toxicity arises from variable combinations of the innate toxicity of the surfactant(s) in a GBH compared to technical glyphosate, the impact of the surfactant(s) on the movement of glyphosate through human skin and into cells, and possible synergistic impacts [30, 37-39].

The EPA goes on to state that it placed greater weight on in vivo genotoxicity assays than on those testing in vitro exposures, especially for the same endpoint and that the only positive in vivo results were seen "at relatively high doses that are not relevant for human health risk assessment" [3].

\section{Need to address and mitigate unusual and high occupational exposures}

The EPA's September 2016 evaluation of glyphosate carcinogenicity is largely focused on typical, expected dietary exposures facing the general public. The EPA's analysis does not encompass occupational and unusual exposure scenarios, nor circumstances where some problem, error, mistake, land use factor, or quirk of nature leads to an unusually high GBH-exposure episode.

Periodically, the EPA issues a report covering glyphosate exposure and health-impact incident reports. For example, between 2002 and 2008, a total of 271 incident reports were compiled by EPA, 36\% of which involved neurological symptoms, $29.5 \%$ dermal irritation, rash, or hives, and $14 \%$ respiratory duress [15]. Common causes of such incidents include a slow leak in a hose or fitting on a backpack sprayer, leading to the drenching over several hours of the applicator's neck, back, and/or legs; repair of an equipment breakdown that inadvertently leads to significant exposure to spray solution; and,

Table 3 Examples of the differential toxicity of technical glyphosate and formulated GBHs in human cell assays

\begin{tabular}{|c|c|c|c|c|}
\hline Assay/marker & Glyphosate technical & Formulated GBHs & Differential & Source \\
\hline Viability of human peripheral blood mononuclear cells & $1640 \mu \mathrm{g} / \mathrm{mL}$ & $56.4 \mu \mathrm{g} / \mathrm{mL}$ & 29 & Martinez et al. [40] \\
\hline LC 50 in HepG2 cells (ppm) & 19,323 & 62 & 312 & Mesnage et al. [33] \\
\hline LC 50 in JEG3 cells (ppm) & 1192 & 32 & 37 & Mesnage et al. [33] \\
\hline 1/LC 50 JEG3 cells (ppm) [glyphosate IPA-salt; Roundup Classic] & 0.000082 & 0.0081 & 99 & Defarge et al. [32] \\
\hline DNA damage to peripheral blood mononuclear cells & $250 \mu \mathrm{M}$ & 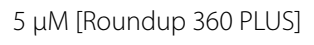 & 50 & Wozniak et al. [34] \\
\hline LC 50 in human HepaRG cells & $2 \mathrm{mg} / \mathrm{mL}$ & $0.04-0.1 \mathrm{mg} / \mathrm{mL}$ & $20-50$ & Rice et al. [41] \\
\hline
\end{tabular}


routine maintenance and service of spraying equipment and tank cleanup procedures. In the case of large-scale spray equipment used to apply a GBH in farm fields or large areas, a person repairing a leaky fitting or valve, or dealing with clogged nozzles or a blown hose, can be heavily exposed in a matter of seconds.

There is a vast array of unusual circumstances leading to elevated- to very-high exposure episodes, compared to typical, "general population" exposures, that do not involve equipment malfunction. Some examples include the following:

- A child playing with a dog that has recently spent time in an area sprayed with a GBH;

- sugar cane harvesters in Central America working in a recently burnt field that had been sprayed 7-10 days earlier with a GBH, creating a possibly toxic mix of smoke and GBH residues;

- an applicator on an ATV or driving a truck-mounted sprayer that covers an area via a concentric-circle spray pattern on a windy day, and

- workers in a rice field adjacent to an irrigation ditch recently treated with a GBH for weed control.

\section{More data needed on the distribution of exposure levels}

Across all occupationally exposed populations, there is a distribution of glyphosate exposure levels ranging from modestly above typical, background levels, to manyfold higher. Only a few studies have reported sufficient data to gain some sense of the distribution of exposure levels in an exposed population. One such study focused on 82 Thai women during their seventh month of pregnancy. Kongtip et al. [42] reported the number of women falling within progressively higher levels of glyphosate in maternal serum and umbilical cord blood. Levels varied by some 100- to 200-fold, as evident in Fig. 1a, b.

The IARC Working Group placed considerable weight on the genotoxicity studies in human populations exposed to formulated GBHs ( $80 \%$ of which were positive), while the EPA did not. These studies reflect highend, real-world human-exposure scenarios more closely than any other category of study. It is true that the populations in these studies lived in or near, or worked around areas heavily treated with formulated GBHs, but it is also highly likely that millions of people around the world applying a GBH on any given day, or living near areas where substantial volumes of GBHs are applied, are also exposed to elevated levels because of application equipment problems, wind conditions, human error, or negligence.

Further research is urgently needed to quantify urine and serum levels of glyphosate following known, high-exposure scenarios. In light of the heightened toxicity of formulated GBHs in contrast to technical glyphosate, research is also needed to determinate the levels of major GBH surfactants and adjuvants in urine and blood, as well as their rate of skin penetration, metabolism and excretion. Such data are essential to sort out whether, and to what degree, GBH adjuvants and surfactants account for the genotoxicity and/or other adverse health effects of GBHs, in contrast to exposure to glyphosate technical.

The data generated by such research and biomonitoring will be valuable for regulators and GBH registrants in two ways. First, it will help guide future changes in coformulants to limit use of those known to increase risks through one or more mechanisms. Second, these data will help sharpen worker-risk assessments and identify under what conditions, and for what uses, additional worker-safety precautions and Personal Protective Equipment (PPE) are warranted.

\section{Why so many bacterial reverse mutation studies?}

Over one-half (51 out of 95) of all registrant-commissioned genotoxicity studies on glyphosate and GBHs report the results of bacterial reverse mutation assays (aka Ames tests). The EPA requires just one bacterial reverse mutation assay on a pesticide active ingredient like glyphosate.

It is not clear why registrants focused so heavily on bacterial reverse mutation assays (54\% of total assays), nearly all of which report the same result (negative). Scientists not affiliated with the industry and publishing in peerreviewed journals pursued different genotoxicity testing priorities and published only seven bacterial reverse mutation assay results (one positive), or $5.7 \%$ of the 122 assays reported in public literature.

In addition to Monsanto, other pesticide companies developed their own set of toxicology studies to support their proprietary GBH brands and hence had to fulfil EPA data requirements (e.g., Syngenta, Cheminova). Still, dozens of bacterial reverse mutation studies were conducted after data requirements were fulfilled and after there was widespread recognition among regulators and companies that glyphosate, and GBHs pose virtually no risk of genotoxicity in bacterial reverse mutation assays. The scientific and regulatory "added value" of so many bacterial reverse mutation studies is questionable, other than increasing the number of negative studies supporting the safety of glyphosate and GBHs. In vitro bacterial reverse mutation assays cost much less to run than nearly all other genotoxicity assays and hence would be among the least expensive options to increase the number of negative assays. 


\section{a Maternal Serum}

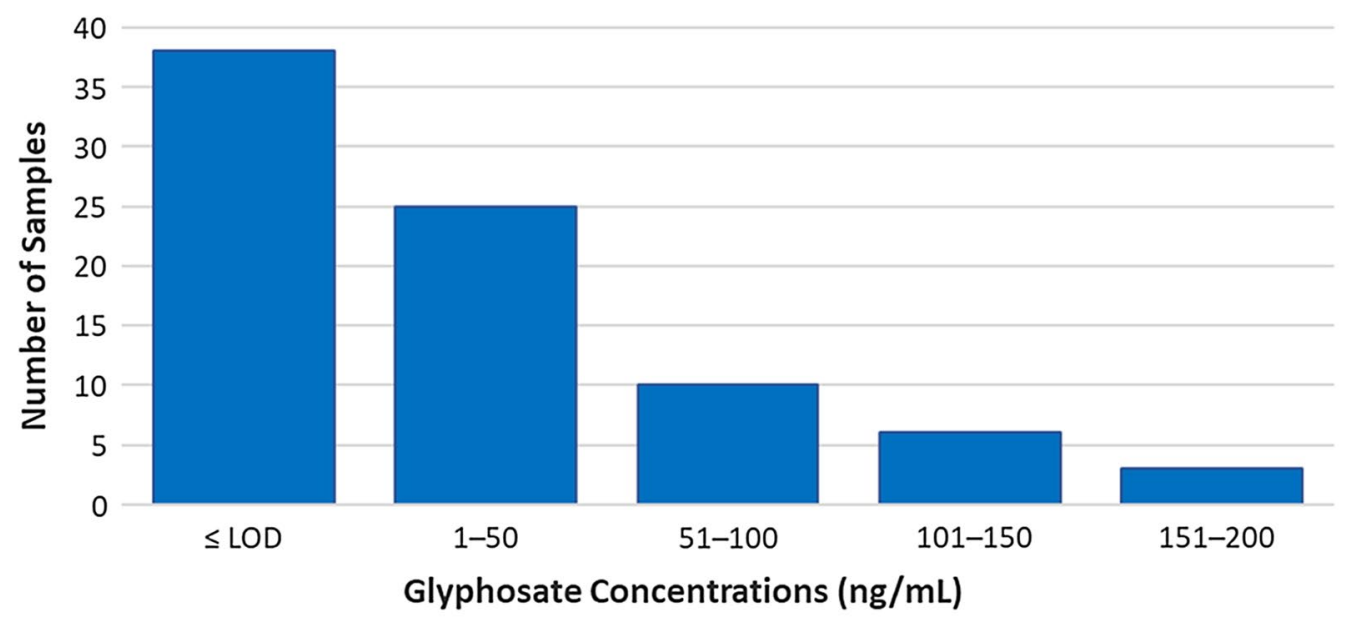

b Umbilical Cord Serum

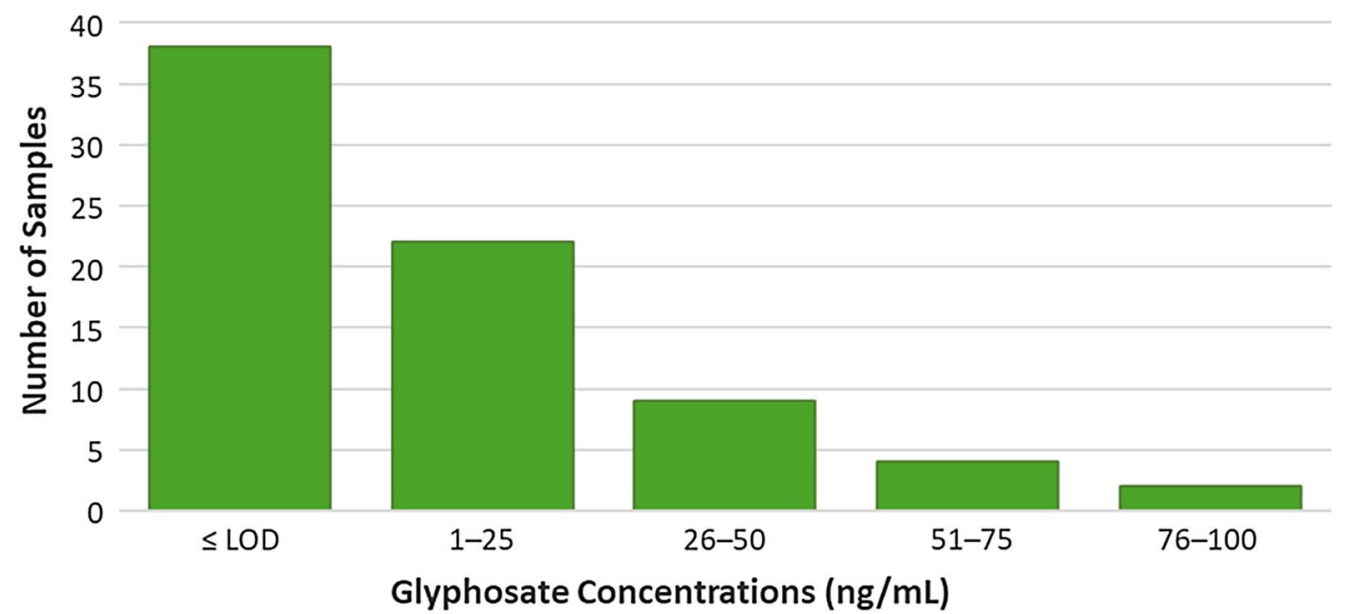

Fig. 1 a, b Range of glyphosate concentrations in maternal and umbilical cord serum. This figure was created using data from Kongtip et al. [42, see Figure 1 for publication.eps]

\section{Different outcomes in regulatory and public literature studies}

Table 1 reports that across all genotoxicity assays on glyphosate technical, just $2 \%$ of studies sponsored by glyphosate registrants reported some positive evidence of a genotoxic response, while $67 \%$ of the studies in peer-reviewed journals reported one or more positive result. Given that the same basic genotoxicity assay systems were used in carrying out most regulatory and public literature studies, this big difference in outcomes begs for an explanation.

In some cases, the authors of regulatory studies report some evidence of a genotoxic response in a given assay, but then classify the study as "negative" because of the following:
- The reported result occurred at an excessive dose level;

- the dose was toxic to cells via a non-genotoxic mechanism; and/or

- the route of administration is regarded as not relevant in human-health risk assessment.

Dozens of examples of the above judgements are described in the Monsanto-commissioned, comprehensive reviews of glyphosate and $\mathrm{GBH}$ genotoxicity assays $[14,22,26,27]$. In general when compared to studies in the peer-reviewed literature, regulatory studies tend to place more weight on factors that can arguably turn a positive assay result into a negative, or equivocal one. The criteria and decision process regulators apply 
in determining whether the authors of regulatory studies are justified in dismissing a given positive result are generally unknown. This is an area in need of further research.

\section{Genotox studies published post-EPA and IARC reviews}

The most recent genotoxicity study evaluated by the IARC Working Group [4] and EPA [3] was published in January 2015 [43]. From February 2015 through December 24, 2018, at least 27 additional studies have been published addressing possible mechanisms of genotoxic action for glyphosate and/or formulated GBHs (see Table 4). All but one of the 27 studies in Table 4 reported one or more positive result: 18 positives arising from DNA damage, 6 associated with oxidative stress, and two with other genotoxicity mechanisms.

These studies lend further support to the IARC Working Group's conclusion that there is "strong evidence" that formulated GBHs can trigger cell damage through at least two mechanisms of action (DNA damage and oxidative stress), thereby possibly triggering or accelerating the progression of cancerous cell growths.

The database supporting assessments of the genotoxicity of glyphosate and GBHs continues to evolve. Ghisi Nde et al. [44] conducted a meta-analysis of studies reporting the formation of micronuclei following exposure to glyphosate and/or GBHs. The team reports that both glyphosate and GBHs increase the frequency of micronuclei formation. Soloneski et al. [45] conducted a study in toads comparing the genotoxic impacts of a $\mathrm{GBH}$, a dicamba-based herbicide, and a combination of these two, formulated herbicides, and concluded that the combination of GBH + dicamba herbicide led to a synergistic effect on the induction of primary DNA breaks. This result is worrisome given that well over one-half of the soybeans planted in the US in 2018 were genetically engineered to resist both GBHs and dicamba, and around two-thirds of national acreage will likely be sprayed in 2019 with this same mixture of herbicides [46, 47].

Currently the National Toxicology Program is conducting in vitro assays comparing the genotoxicity of glyphosate technical and several glyphosate formulations, as well as conducting a comprehensive literature review of the current database on glyphosate genotoxicity. Their full report has not been published, but a poster presented at the 2018 Society of Toxicology Conference reported the results of several assays on human HepaRG and $\mathrm{HeCaT}$ cell lines [41]. CellTiter-Glo, ROS-Glo, and JC10 assays on both cell lines revealed significant impacts on cell viability and alteration of mitochondrial membrane potential for both glyphosate and glyphosate-based formulations. In addition, GBHs were substantially more toxic than glyphosate alone. The glyphosate formulations studied decreased cell viability by more than $90 \%$ at concentrations "approximately 20- to 50-fold lower than glyphosate" [41].

\section{Debate likely to persist}

The scientific debate over the genotoxicity and oncogenic potential of GBHs is ongoing. While both the EPA and EFSA consider the glyphosate database to be essentially complete relative to current testing requirements, critical knowledge and data gaps persist in three areas: (1) welldesigned 2-year feeding studies in mice and rats fed formulated GBHs; (2) data on occupational exposures and risk under a diversity of scenarios, including atypical but recurrent handling and application scenarios that lead to markedly elevated exposures; and (3) modern, rigorous data on the rate of skin penetration of the glyphosate and co-formulants in GBHs, in contrast to rates of penetration from studies conducted using technical glyphosate. Ideally, to build confidence in study results, each of the above sets of studies should be undertaken both by registrants in accord with testing guidance from regulators, and by scientists not affiliated with, or funded by pesticide registrants or their allied organizations.

\section{Conclusions}

According to EPA, glyphosate technical does not pose oncogenic risk at "relevant" levels of exposure, i.e. those levels likely to occur among members of the general public from "typical" dietary exposures. In reaching its "not likely to be oncogenic" conclusion, the EPA (1) largely ignored epidemiological studies, some of which reported elevated, statistically significant odds ratios among cohorts that were relatively more highly exposed to GBHs and, (2) placed little or no weight on multiple in vivo GBH genotoxicity assays that reported DNA damage and/or oxidative stress in laboratory animals and exposed human cohorts.

IARC, on the other hand, placed considerable weight on studies linking use of, and exposure to GBHs to cancer, as well as evidence of DNA damage and oxidative stress in human populations exposed to GBHs. The science base reviewed by IARC included adverse impacts among some people much more heavily exposed than a typical person in the US or Europe. Hence, the IARC Working Group's weight-of-evidence judgement that GBHs are "probably carcinogenic to humans" is most appropriately applied to those humans who are relatively more heavily exposed to GBHs. In fact, had the IARC Working Group restricted its assessment of GBH oncogenicity in ways comparable to the limits embedded in the assessments conducted by the EPA and EFSA, it is 


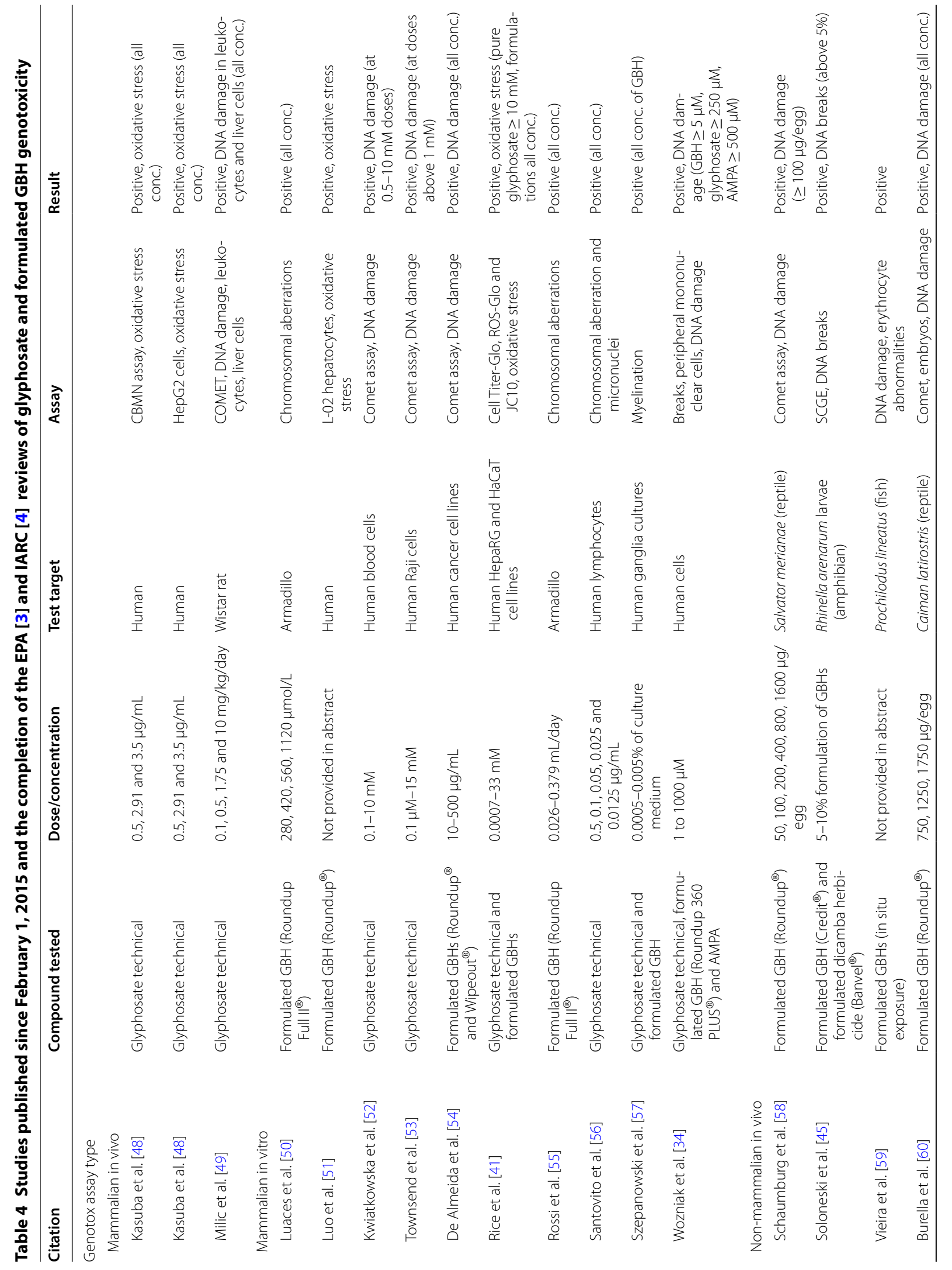




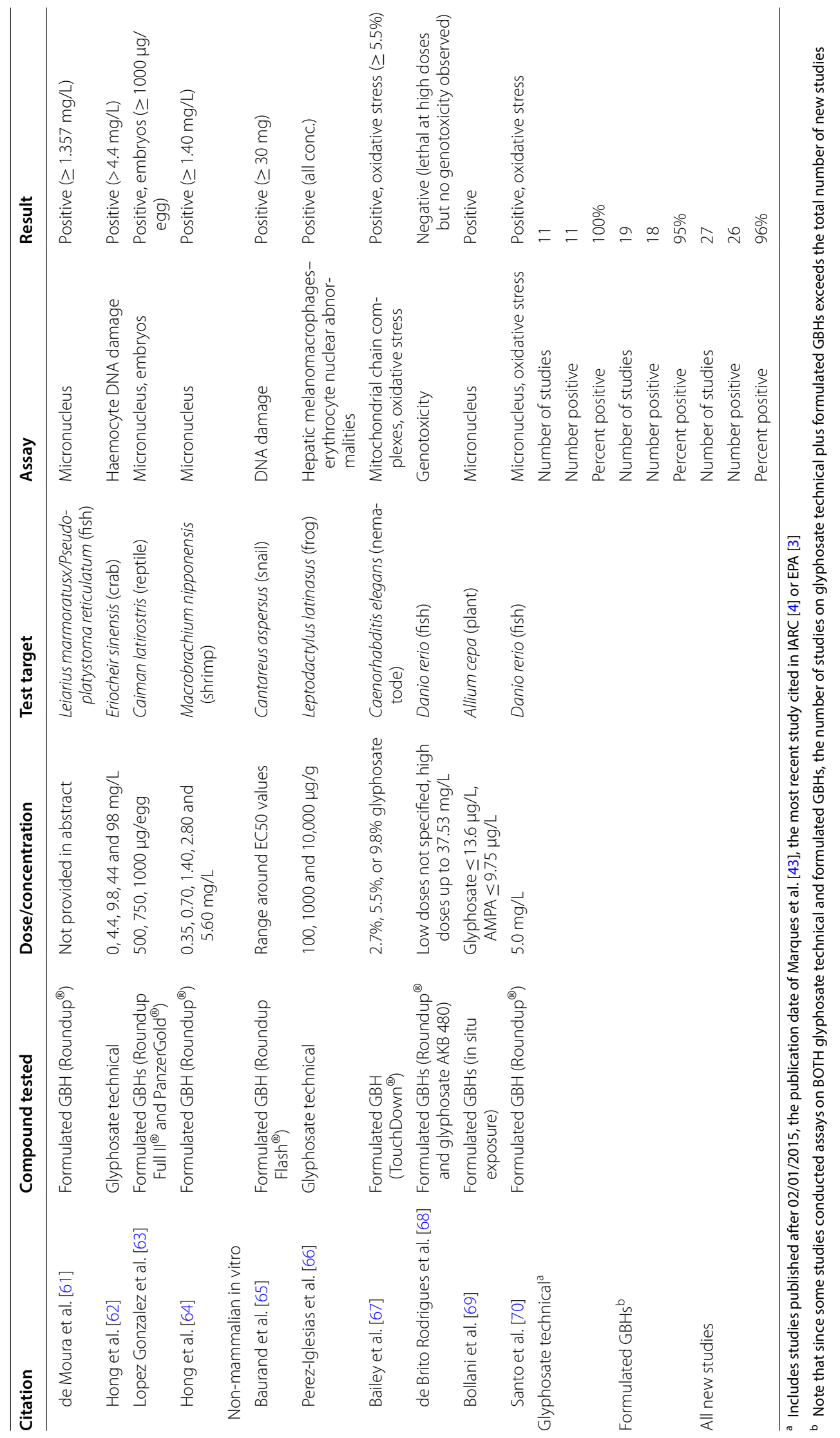


likely that the IARC Working Group would not have classified glyphosate as Group 2A, "probably carcinogenic to humans."

Ongoing research, regulatory risk assessments, and debate over glyphosate and GBH carcinogenicity and genotoxicity should be focused on studies relevant to the biological impacts triggered by exposures to widely used, formulated GBHs.

The laws and policies governing EPA regulatory decision-making direct the agency to carefully assess exposures and typical, expected risks to the general public and environment from pesticide applications made in accord with label directions and required safety precautions. Much less effort has been invested by EPA in assuring that occupational and worker-risk assessments are based on accurate exposure and toxicological data. Such scenarios should include when, where, how, and how frequently and heavily a formulated GBH is applied by a given person. Risk assessments, pesticide label directions, pesticide applicator training and certification curricula, and health-related warnings to applicators should address scenarios when hoses leak, spills occur, the wind blows in unexpected ways, clothes are drenched and need to be handled safely, and other unusual circumstances leading to higher-than-normal exposures.

While unusually high-exposure scenarios generally arise from some combination of equipment malfunction, operator error or carelessness, or working in or near a recently treated field or area, the frequency of such episodes is a function of the diversity and number of applications made. In the case of glyphosate-based herbicides, the world's most widely used pesticide ever, such relatively high-exposure episodes occur tens of thousands of times on a daily basis in the US and hundreds of thousands, if not millions of times globally.

IARC's evaluation relied heavily on studies capable of shedding light on the distribution of real-world exposures and genotoxicity risk in exposed human populations, while EPA's evaluation placed little or no weight on such evidence.

\section{Additional file}

Additional file 1. Additional tables.

\section{Abbreviations}

AMPA: aminomethylphosphonic acid; EFSA: European Food Safety Authority; EPA: United States Environmental Protection Agency; GBH: glyphosate-based herbicide; IARC: International Agency for Research on Cancer; NTP: National Toxicology Program.

\section{Authors' contributions}

CB designed the study, compiled the data, carried out the analysis, and wrote the paper. The author read and approved the final manuscript.

\section{Acknowledgements}

The author wishes to thank the 10 reviewers for their many constructive comments on ways to strengthen and clarify the paper, as well as their attention to detail, and also appreciates the assistance of Rachel Benbrook in the design of the tables and figures in this paper, and in securing and properly citing references.

\section{Competing interests}

CB has served since September 2016 as an expert witness for plaintiffs in US litigation involving the impact of glyphosate-based herbicides on non-Hodgkin lymphoma. His work as an expert witness has included assessment of the genotoxicity databases relied upon by the EPA and IARC in their evaluations of GBH carcinogenicity. Lawyers involved in the litigation had no role in the decision to write this paper, nor in reviewing or commenting on its content. In the past, CB has also served as an expert witness in litigation focused on whether foods containing ingredients from genetically-engineered crops can be labeled "natural" without misleading consumers. His work since 1981 on pesticide use, risks, and regulation has been supported by state and federal agencies, the US Congress, the US National Academy of Sciences, foundations, NGOs, pesticide manufacturers, and the food industry, including organic food and farming companies and organizations.

\section{Availability of data and materials}

The 11 additional tables used to conduct the analysis reported herein are available in Additional file 1.

\section{Consent for publication}

Not applicable.

Ethics approval and consent to participate

Not applicable.

\section{Funding}

CB thanks the Ceres Trust for the grant to the Children's Environmental Health Network that supported the preparation and publication of this manuscript.

\section{Publisher's Note}

Springer Nature remains neutral with regard to jurisdictional claims in published maps and institutional affiliations.

Received: 23 November 2018 Accepted: 28 December 2018

Published online: 14 January 2019

\section{References}

1. BfR (2013) Renewal assessment report: glyphosate, toxicology and metabolism. https://hygeia-analytics.com/wp-content/uploads/2019/01/ Glyphosate_RAR_08_Volume_3CA-CP_B-6_2013-12-18.pdf. Accessed 11 Nov 2018

2. EFSA (2015) Conclusion on the peer review of the pesticide risk assessment of the active substance glyphosate. EFSA J 13:4302. https://doi. org/10.2903/j.efsa.2015.4302

3. EPA (2016) Glyphosate issue paper: evaluation of carcinogenic potential. https://www.epa.gov/sites/production/files/2016-09/documents/glyph osate_issue_paper_evaluation_of_carcincogenic_potential.pdf. Accessed 10 Apr 2018

4. IARC (2017) IARC Monographs on the evaluation of carcinogenic risks to humans-volume 112: some organophosphate insecticides and herbicides. https://monographs.iarc.fr/wp-content/uploads/2018/07/mono1 12.pdf. Accessed 10 June 2018

5. Bolognesi C, Carrasquilla G, Volpi S, Solomon KR, Marshall EJ (2009) Biomonitoring of genotoxic risk in agricultural workers from five Colombian regions: association to occupational exposure to glyphosate. J Toxicol Environ Health Part A 72:986-997. https://doi.org/10.1080/1528739090 2929741 
6. Astiz M, de Alaniz MJ, Marra CA (2009) Antioxidant defense system in rats simultaneously intoxicated with agrochemicals. Environ Toxicol Pharmacol 28:465-473. https://doi.org/10.1016/j.etap.2009.07.009

7. Gehin A, Guillaume YC, Millet J, Guyon C, Nicod L (2005) Vitamins C and E reverse effect of herbicide-induced toxicity on human epidermal cells HaCaT: a biochemometric approach. Int J Pharm 288:219-226. https:// doi.org/10.1016/j.ijpharm.2004.09.024

8. Guyton KZ et al (2015) Carcinogenicity of tetrachlorvinphos, parathion, malathion, diazinon, and glyphosate. Lancet Oncol 16:490-491. https:// doi.org/10.1016/S1470-2045(15)70134-8

9. Portier CJ et al (2016) Differences in the carcinogenic evaluation of glyphosate between the International Agency for Research on Cancer (IARC) and the European Food Safety Authority (EFSA). J Epidemiol Community Health 70:741-745. https://doi.org/10.1136/jech-2015-207005

10. Davoren MJ, Schiestl RH (2018) Glyphosate-based herbicides and cancer risk: a post-IARC decision review of potential mechanisms, policy and avenues of research. Carcinogenesis 39:1207-1215. https://doi. org/10.1093/carcin/bgy105

11. Landrigan PJ, Belpoggi $F$ (2018) The need for independent research on the health effects of glyphosate-based herbicides. Environ Health 17:51. https://doi.org/10.1186/s12940-018-0392-z

12. Acquavella J, Garabrant D, Marsh G, Sorahan T, Weed DL (2016) Glyphosate epidemiology expert panel review: a weight of evidence systematic review of the relationship between glyphosate exposure and non-Hodgkin's lymphoma or multiple myeloma. Crit Rev Toxicol 46:28-43. https:// doi.org/10.1080/10408444.2016.1214681

13. McClellan RO (2016) Evaluating the potential carcinogenic hazard of glyphosate. Crit Rev Toxicol 46:1-2. https://doi.org/10.1080/10408 444.2016.1234117

14. Williams GM et al (2016) A review of the carcinogenic potential of glyphosate by four independent expert panels and comparison to the IARC assessment. Crit Rev Toxicol 46:3-20. https://doi.org/10.1080/10408 444.2016.1214677

15. Hawkins M, Cordova J (2009) Updated review of glyphosate (103601) Incident Reports, Office of Pesticide Programs, Environmental Protection Agency. https://hygeia-analytics.com/wp-content/uploads/2019/01/ RUP-EPA-archives-2009-2-26-review-of-incident-reports-lots-of-DERMA L.pdf. Accessed 3 Nov 2018

16. EPA (2005) Guidelines for carcinogen risk assessment. https://www3.epa. gov/airtoxics/cancer_guidelines_final_3-25-05.pdf. Accessed 10 Aug 2018

17. IARC (2018) Agents classified by the IARC monographs, volumes 1-123. https://monographs.iarc.fr/agents-classified-by-the-iarc/. Accessed 21 Nov 2018

18. Canadian Pest Management Regulatory Agency (2017) Re-evaluation decision RVD2017-01, glyphosate. https://www.canada.ca/en/healt h-canada/services/consumer-product-safety/reports-publications/pesti cides-pest-management/decisions-updates/registration-decision/2017/ glyphosate-rvd-2017-01.html. Accessed 10 Dec 2018

19. Richmond ME (2018) Glyphosate: a review of its global use, environmental impact, and potential health effects on humans and other species. J Environ Stud Sci 8:416-434. https://doi.org/10.1007/s13412-018-0517-2

20. Clausing P, Robinson C, Burtscher-Schaden H (2018) Pesticides and public health: an analysis of the regulatory approach to assessing the carcinogenicity of glyphosate in the European Union. J Epidemiol Community Health 72:668-672. https://doi.org/10.1136/jech-2017-209776

21. Székács A, Darvas B (2018) Re-registration challenges of glyphosate in the European Union. Front Environ Sci 6:78. https://doi.org/10.3389/fenvs .2018 .00078

22. Brusick D, Aardema M, Kier L, Kirkland D, Williams G (2016) Genotoxicity Expert Panel review: weight of evidence evaluation of the genotoxicity of glyphosate, glyphosate-based formulations, and aminomethylphosphonic acid. Crit Rev Toxicol 46:56-74. https://doi.org/10.1080/10408 444.2016.1214680

23. Tarazona JV, Court-Marques D, Tiramani M, Reich H, Pfeil R, Istace F, Crivellente $F$ (2017) Glyphosate toxicity and carcinogenicity: a review of the scientific basis of the European Union assessment and its differences with IARC. Arch Toxicol 91:2723-2743. https://doi.org/10.1007/s0020 4-017-1962-5
24. Vandenberg LN et al (2017) Is it time to reassess current safety standards for glyphosate-based herbicides? J Epidemiol Community Health 71:613-618. https://doi.org/10.1136/jech-2016-208463

25. IARC (2018) Briefing note for IARC scientific and governing council members. http://governance.iarc.fr/ENG/Docs/BriefingGCSC_FINAL_29012 018.pdf. Accessed 19 Dec 2018

26. Heydens WF, Healy CE, Hotz KJ, Kier LD, Martens MA, Wilson AG, Farmer DR (2008) Genotoxic potential of glyphosate formulations: mode-ofaction investigations. J Agric Food Chem 56:1517-1523. https://doi. org/10.1021/jf072581i

27. Kier LD, Kirkland DJ (2013) Review of genotoxicity studies of glyphosate and glyphosate-based formulations. Crit Rev Toxicol 43:283-315. https:// doi.org/10.3109/10408444.2013.770820

28. Paz-y-Miño C et al (2011) Baseline determination in social, health, and genetic areas in communities affected by glyphosate aerial spraying on the northeastern Ecuadorian border. Rev Environ Health 26:45-51. https ://doi.org/10.1515/reveh.2011.007

29. Paz-y-Miño C, Sánchez ME, Arévalo M, Muñoz MJ, Witte T, De-la-Carrera GO, Leone PE (2007) Evaluation of DNA damage in an Ecuadorian population exposed to glyphosate. Genet Mol Biol 30:456-460. https://doi. org/10.1590/S1415-47572007000300026

30. Kim Y-H, Hong J-R, Gil H-W, Song H-Y, Hong S-Y (2013) Mixtures of glyphosate and surfactant TN20 accelerate cell death via mitochondrial damage-induced apoptosis and necrosis. Toxicol In Vitro 27:191-197. https://doi.org/10.1016/j.tiv.2012.09.021

31. Mesnage R, Defarge N, Spiroux de Vendomois J, Seralini G-E (2014) Major pesticides are more toxic to human cells than their declared active principles. Biomed Res Int 2014:179691. https://doi.org/10.1155/2014/179691

32. Defarge N, Takács E, Lozano V, Mesnage R, Spiroux de Vendômois J, Séralini G-E, Székács A (2016) Co-formulants in glyphosate-based herbicides disrupt aromatase activity in human cells below toxic levels. Int J Environ Res Public Health 13:264. https://doi.org/10.3390/ijerph13030264

33. Mesnage R, Bernay B, Seralini GE (2013) Ethoxylated adjuvants of glyphosate-based herbicides are active principles of human cell toxicity. Toxicology 313:122-128. https://doi.org/10.1016/j.tox.2012.09.006

34. Wozniak E et al (2018) The mechanism of DNA damage induced by Roundup 360 PLUS, glyphosate and AMPA in human peripheral blood mononuclear cells - genotoxic risk assessement. Food Chem Toxicol 120:510-522. https://doi.org/10.1016/j.fct.2018.07.035

35. Mesnage R, Defarge N, Spiroux de Vendomois J, Seralini GE (2015) Potential toxic effects of glyphosate and its commercial formulations below regulatory limits. Food Chem Toxicol 84:133-153. https://doi. org/10.1016/j.fct.2015.08.012

36. Nobels I, Spanoghe P, Haesaert G, Robbens J, Blust R (2011) Toxicity ranking and toxic mode of action evaluation of commonly used agricultural adjuvants on the basis of bacterial gene expression profiles. PLOS ONE 6:e24139. https://doi.org/10.1371/journal.pone.0024139

37. Albanil Sanchez JA, da Costa Klosterhoff M, Romano LA, De Martinez Gaspar Martins C (2018) Histological evaluation of vital organs of the livebearer Jenynsia multidentata (Jenyns, 1842) exposed to glyphosate: a comparative analysis of Roundup ${ }^{\circledR}$ formulations. Chemosphere 217:914-924. https://doi.org/10.1016/j.chemosphere.2018.11.020

38. Xie $L$ et al (2005) Evaluation of estrogenic activities of aquatic herbicides and surfactants using an rainbow trout vitellogenin assay. Toxicol Sci 87:391-398. https://doi.org/10.1093/toxsci/kfi249

39. Tsui MTK, Chu LM (2003) Aquatic toxicity of glyphosate-based formulations: comparison between different organisms and the effects of environmental factors. Chemosphere 52:1189-1197. https://doi.org/10.1016/ S0045-6535(03)00306-0

40. Martinez A, Reyes I, Reyes N (2007) Cytotoxicity of the herbicide glyphosate in human peripheral blood mononuclear cells. Biomedica 27:594-604

41. Rice JR, Dunlap P, Ramaiahgari S, Ferguson S, Smith-Roe SL, DeVito M (2018) Poster: effects of glyphosate and its formulations on markers of oxidative stress and cell viability in HepaRG and $\mathrm{HaCaT}$ cell lines. Society of Toxicology Conference. https://usrtk.org/wp-content/uploa ds/2018/05/NTP_GBF-paper.pdf. Accessed 7 Dec 2018

42. Kongtip P et al (2017) Glyphosate and Paraquat in maternal and fetal serums in Thai women. J Agromed 22:282-289. https://doi. org/10.1080/1059924x.2017.1319315 
43. Marques A, Guilherme S, Gaivão I, Santos MA, Pacheco M (2015) Erratum to: "Progression of DNA damage induced by a glyphosate-based herbicide in fish (Anguilla anguilla) upon exposure and post-exposure periods - insights into the mechanisms of genotoxicity and DNA repair" [Comp. Biochem. Physiol. C 166 (2014) 126-133]. Comp Biochem Physiol C Toxicol Pharmacol 168:1. https://doi.org/10.1016/j.cbpc.2014.10.008

44. Ghisi Nde C, de Oliveira EC, Prioli AJ (2016) Does exposure to glyphosate lead to an increase in the micronuclei frequency? A systematic and meta-analytic review. Chemosphere 145:42-54. https://doi.org/10.1016/j. chemosphere.2015.11.044

45. Soloneski S, Ruiz de Arcaute C, Larramendy ML (2016) Genotoxic effect of a binary mixture of dicamba- and glyphosate-based commercial herbicide formulations on Rhinella arenarum (Hensel, 1867) (Anura, Bufonidae) late-stage larvae. Environ Sci Pollut Res 23:17811-17821. https://doi. org/10.1007/s11356-016-6992-7

46. Benbrook C (2016) Trends in glyphosate herbicide use in the United States and globally. Environ Sci Europe 28:3. https://doi.org/10.1186/ s12302-016-0070-0

47. Bennett D (2018) Monsanto responds to increased dicamba drift reports. Delta FarmPress. https://www.farmprogress.com/soybean/monsantoresponds-increased-dicamba-drift-reports. Accessed 4 Dec 2018

48. Kasuba $V$ et al (2017) Effects of low doses of glyphosate on DNA damage, cell proliferation and oxidative stress in the HepG2 cell line. Environ Sci Pollut Res 24:19267-19281. https://doi.org/10.1007/s11356-017-9438-y

49. Milic M et al (2018) Oxidative stress, cholinesterase activity, and DNA damage in the liver, whole blood, and plasma of Wistar rats following a 28-day exposure to glyphosate. Arch Ind Hyg Toxicol 69:154-168. https:// doi.org/10.2478/aint-2018-69-3114

50. Luaces JP, Rossi LF, Chirino MG, Browne M, Merani MS, Mudry MD (2017) Genotoxic effects of Roundup Full II(R) on lymphocytes of Chaetophractus villosus (Xenarthra, Mammalia): in vitro studies. PLoS ONE 12:e0182911. https://doi.org/10.1371/journal.pone.0182911

51. Luo L, Wang F, Zhang Y, Zeng M, Zhong C, Xiao F (2017) In vitro cytotoxicity assessment of roundup (glyphosate) in L-02 hepatocytes. J Environ Sci Health Part B 52:410-417. https://doi.org/10.1080/03601234.2017.12934 49

52. Kwiatkowska M, Reszka E, Wozniak K, Jablonska E, Michalowicz J, Bukowska B (2017) DNA damage and methylation induced by glyphosate in human peripheral blood mononuclear cells (in vitro study). Food Chem Toxicol 105:93-98. https://doi.org/10.1016/j.fct.2017.03.051

53. Townsend M, Peck C, Meng W, Heaton M, Robison R, O'Neill K (2017) Evaluation of various glyphosate concentrations on DNA damage in human Raji cells and its impact on cytotoxicity. Regul Toxicol Pharmacol 85:79-85. https://doi.org/10.1016/j.yrtph.2017.02.002

54. De Almeida LKS, Pletschke Bl, Frost CL (2018) Moderate levels of glyphosate and its formulations vary in their cytotoxicity and genotoxicity in a whole blood model and in human cell lines with different estrogen receptor status. 3 Biotech 8:438. https://doi.org/10.1007/s1320 5-018-1464-z

55. Rossi LF, Luaces JP, Palermo AM, Merani MS, Mudry MD (2018) Cytogenetic damage in peripheral blood cultures of Chaetophractus villosus exposed in vivo to a glyphosate formulation (Roundup). Ecotoxicol Environ Saf 157:121-127. https://doi.org/10.1016/j.ecoenv.2018.03.046

56. Santovito A, Ruberto S, Gendusa C, Cervella P (2018) In vitro evaluation of genomic damage induced by glyphosate on human lymphocytes. Environ Sci Pollut Res Int. https://doi.org/10.1007/s11356-018-3417-9

57. Szepanowski F, Szepanowski LP, Mausberg AK, Albrecht P, Kleinschnitz C, Kieseier BC, Stettner M (2018) Differential impact of pure glyphosate and glyphosate-based herbicide in a model of peripheral nervous system myelination. Acta Neuropathol. https://doi.org/10.1007/s0040 1-018-1938-4

58. Schaumburg LG, Siroski PA, Poletta GL, Mudry MD (2016) Genotoxicity induced by Roundup(R) (glyphosate) in tegu lizard (Salvator merianae) embryos. Pestic Biochem Physiol 130:71-78. https://doi.org/10.1016/j. pestbp.2015.11.009

59. Vieira CE et al (2016) Multiple biomarker responses in Prochilodus lineatus subjected to short-term in situ exposure to streams from agricultural areas in Southern Brazil. Sci Total Environ 542:44-56. https://doi. org/10.1016/j.scitotenv.2015.10.071

60. Burella PM, Simoniello MF, Poletta GL (2017) Evaluation of stage-dependent genotoxic effect of roundup ((R)) (glyphosate) on Caiman latirostris embryos. Arch Environ Contam Toxicol 72:50-57. https://doi.org/10.1007/ s00244-016-0311-7

61. de Moura FR et al (2017) Effects of glyphosate-based herbicide on pintado da Amazonia: hematology, histological aspects, metabolic parameters and genotoxic potential. Environ Toxicol Pharmacol 56:241-248. https://doi.org/10.1016/j.etap.2017.09.019

62. Hong $Y$ et al (2017) Effects of glyphosate on immune responses and haemocyte DNA damage of Chinese mitten crab, Eriocheir sinensis. Fish Shellfish Immunol 71:19-27. https://doi.org/10.1016/j.fsi.2017.09.062

63. Lopez Gonzalez EC, Larriera A, Siroski PA, Poletta GL (2017) Micronuclei and other nuclear abnormalities on Caiman latirostris (Broad-snouted caiman) hatchlings after embryonic exposure to different pesticide formulations. Ecotoxicol Environ Saf 136:84-91. https://doi.org/10.1016/j. ecoenv.2016.10.035

64. Hong $Y$, Yang $X$, Huang $Y$, Yan G, Cheng Y (2018) Assessment of the oxidative and genotoxic effects of the glyphosate-based herbicide Roundup on the freshwater shrimp, Macrobrachium nipponensis. Chemosphere 210:896-906. https://doi.org/10.1016/j.chemosphere.2018.07.069

65. Baurand PE, Capelli N, de Vaufleury A (2015) Genotoxicity assessment of pesticides on terrestrial snail embryos by analysis of random amplified polymorphic DNA profiles. J Hazard Mater 298:320-327. https://doi. org/10.1016/j.jhazmat.2015.05.051

66. Perez-Iglesias JM, Franco-Belussi L, Moreno L, Tripole S, de Oliveira C, Natale GS (2016) Effects of glyphosate on hepatic tissue evaluating melanomacrophages and erythrocytes responses in neotropical anuran Leptodactylus latinasus. Environ Sci Pollut Res Int 23:9852-9861. https:// doi.org/10.1007/s11356-016-6153-z

67. Bailey DC et al (2018) Chronic exposure to a glyphosate-containing pesticide leads to mitochondrial dysfunction and increased reactive oxygen species production in Caenorhabditis elegans. Environ Toxicol Pharmacol 57:46-52. https://doi.org/10.1016/j.etap.2017.11.005

68. de Brito Rodrigues L et al (2017) Ecotoxicological assessment of glyphosate-based herbicides: effects on different organisms. Environ Toxicol Chem 36:1755-1763. https://doi.org/10.1002/etc.3580

69. Bollani S, de Cabo L, Chagas C, Moretton J, Weigandt C, de lorio AF, Magdaleno A (2018) Genotoxicity of water samples from an area of the Pampean region (Argentina) impacted by agricultural and livestock activities. Environ Sci Pollut Res Int. https://doi.org/10.1007/s11356-018-3263-9

70. Santo GD et al (2018) Protective effect of Uncaria tomentosa extract against oxidative stress and genotoxicity induced by glyphosateRoundup(R) using zebrafish (Danio rerio) as a model. Environ Sci Pollut Res Int 25:11703-11715. https://doi.org/10.1007/s11356-018-1350-6 